\title{
Manglande tryggleik i medisinforsyninga
}

\author{
Den akutte mangelen på erytromycin er dessverre berre den siste i ei rekkje liknande skandalar. Då Medi- \\ sinaldepotet forsvann, falt bufferlageret bort og tryggleiken vart borte i det reformerte apotekvesenet. Lege- \\ middelverket må gripe inn og sikre fagleg forsvarleg forsyning til befolkninga.
}

Underteikna var i si tid ein av dei som sterkast åtvara mot frisleppa i apotekvesenet, med fjerning av behovsparagraf og bortfall av bufferlager då Medisinaldepotet forsvann. Saka verserte i media, og blei løfta fram i «Puls» då det i si tid ikkje let seg gjere å skaffe mikstur av ein syrepumpehemmar, med den følgje at ein multifunksjonshemma pleiepasient faktisk døydde $(1,2)$. Sidan har det vore ergring mest kvar veke når meldingane kjem at dette eller hint der den tidlegare kjernevaren, apotekvesenet sitt livsrettgrunnlag, medisinane, får ein stadig mindre plass i sortimentet. Det viktigaste er blitt å selje mykje, ikkje å selje rett. Tidlegare hadde ein apotektilsett ofte gjort ein god jobb om råda kunden fekk, gjorde at denne gjekk tomhendt frå apoteket (4). Nå blir han eller ho dynga ned med kundetilbod, drops, kremar og kosmetika om stakkaren kjem innom for å få seg nødvendig medisin!

\section{«Apoteket har utvikla seg til ei slags parfymerikrambu»}

preparat står i rest eller ikkje lenger lar seg skaffe. Vi tenkte lenge at lukkeleg var den pasienten som hadde ein dusinsjukdom sidan medisinføretaka blei styrte av økonomar, ikkje av farmasøytar lenger (3). Då gjaldt ikkje lenger anna ein bodet om forteneste, ikkje behovet til befolkninga, og lager var ein utgiftspost, ikkje ei tryggingsåtgjerd. Så erfarer vi ganske kjapt at det ikkje berre er nisjepreparata som forsvinn. Billege og velprøvde middel blir tatt bort i hopetal, stadig nye kopiar blir registrerte av dusinpreparata. Men dei lar seg sjeldan skaffe og namna på midla med same virkestoffet, til liks med farge og form, endrar seg frå gong til gong når brukaren skal hente medisinane sine, til stor frustrasjon for pasienten og med til dels katastrofale resultat i form av kaotisk bruk eller ikkje bruk av heilt nødvendig medisin.

Apoteket har utvikla seg til ei slags parfymerikrambu der det meste bys fram, men
Vi har vore gjennom periodar med fem dagars forsyning att av insulin i landet, er gått tomme for vitamin $\mathrm{B}_{12}$, for betablokkarar (heilt nødvendige hjartemedisinar med andre ord), øyredropar, allergimedisin i høgsesongen («Det gjekk så mykje at kjeden ikkje greidde å skaffa nok!» Bjørkesesongen kjem kvart år i april/mai!!), eksemmiddel, betennelsesdempande ... ja, lista kan gjerast nær endelaus. Begeret har vore breiddfullt lenge, men så rann det for alvor over att. Problemet nå er at det faktisk er tomt for den mest brukte antibiotikamiksturen for born, Abboticin, og argumentet er at det er så mange som er sjuke nett nå! På ettervinteren er det luftvegsinfeksjonstid, og det er fullstendig uansvarleg at det ikkje finst sikring med lagre for slike periodar som kjem årvisst. Endå verre blir stoda når heller ikkje alternativa lar seg skaffe ... av same grunn!

Legemiddelverket $m a ̊$ ta tak i dette nå og sikre fagleg forsvarleg forsyning til befolkninga vår! Få økonomane vekk frå styret i kjedene og la farmasøytane legge si stødige hand på rattet. At eg på ingen måte har tru på at politikarane verken har vilje eller evne til å gjere noko med det, er ei kjensgjerning, men stundom kan ein få tru på under. Kan hende kjem dei ut av sitt politiske kritthus når barn eller barnebarn blir sjuke og treng behandling, men slik faktisk ikkje lar seg skaffe fordi maksimal forteneste nå er einaste lova som rår i apotekvesenet!

\section{Svein Gisle Apeland \\ kanape@online.no \\ Breidablikk legekontor \\ Haugesund}

Svein Gisle Apeland (f. 1953) er spesialist i allmennmedisin og har drive som allmennlege i Haugesund frå 1982 med unntak av 1994. då han jobba som assistentlege ved Psykiatrisk avdeling, Haugesund sjukehus.

Forfatter har fylt ut ICMJE-skjemaet og oppgir ingen interessekonflikter.

Litteratur

1. Puls NRK 20.10.2003.

2. Norge har ingen legemiddelberedskap. Dagsavisen 24.10.2003.

3. Hamran 0. Et lite, korrupt gammelt vesen - apotekene og apotekloven av 2001. Tidsskr Nor Legeforen 2011; 131: 1311-5.

4. Hamran O. Riktig medisin? En historie om apotekvesenet. Oslo: Pax, 2010.

Mottatt 29.2. 2012 og godkjent 22.3. 2012. Medisinsk redaktør Anne Kveim Lie. 